\title{
Autumn migration of Jack Snipe Lymnocryptes minimus in southern Sweden: results from ten years of crepuscular ringing
}

\author{
Höstflyttning hos dvärgbeckasin \\ Lymnocryptes minimus i södra Sverige: \\ resultat från tio års ringmärkning kvällstid
}

\author{
Adam Bergner (iD, Christer Elderud, Kent Person \& Lars Gezelius \\ Tåkern Field Station, Renstad Åsen 2, S-596 95 Väderstad, Sweden | adam.bergner@gmail.com, christer@elderud.se, \\ kent.person51@gmail.com \& gezelius.lars@gmail.com
}

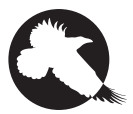

THE AUTUMN MIGRATION of Jack Snipe Lymnocryptes minimus was studied using mist-netting at night along a muddy shoreline at Lake Tåkern in southern central Sweden. During ten consecutive autumn seasons ranging from mid-September to mid-November a total of 107 birds were captured, particularly within the first two hours after dusk. The peak of migration occurred in the first ten days of October with the juvenile birds on average passing a few days earlier than the adult birds. We present information on movements and ringing recoveries and review the challenges of ageing the species. We propose that crepuscular mist-netting near wetlands offering important staging grounds may be a suitable method to monitor the migratory movements, and possibly the population dynamics, of this little-studied species.

Keywords: wetland | ageing | stopover | wader | shorebird

\section{Introduction}

The Jack Snipe Lymnocryptes minimus is a small wader Simmons 1983). The species is generally migratory and breeding in boreal mires and wet tundra from northern exhibits a migratory divide near the $45^{\circ} \mathrm{E}$ longitude, Fennoscandia northeast to eastern Siberia (Cramp \& where birds breeding west thereof have their main win- 
tering grounds in the British Isles, southwest Europe, and northwestern Africa (Smiddy 2002, Fransson et al. 2008), whereas birds breeding east thereof are believed to be long-distance migrants with wintering grounds in sub-Saharan Africa (Taylor 1988). An unknown but not insignificant number of birds occasionally winter in northern Europe near streams and ponds offering ice-free conditions (e.g. Pedersen 1995, Sikora \& Maniakowski 2000).

A majority of the global population of Jack Snipe, at least $90 \%$, is believed to breed in Russia, and since large parts of the species' distribution range is confined to areas lacking permanent human settlements there is limited reliable information on the size of the breeding population. Its current status and population

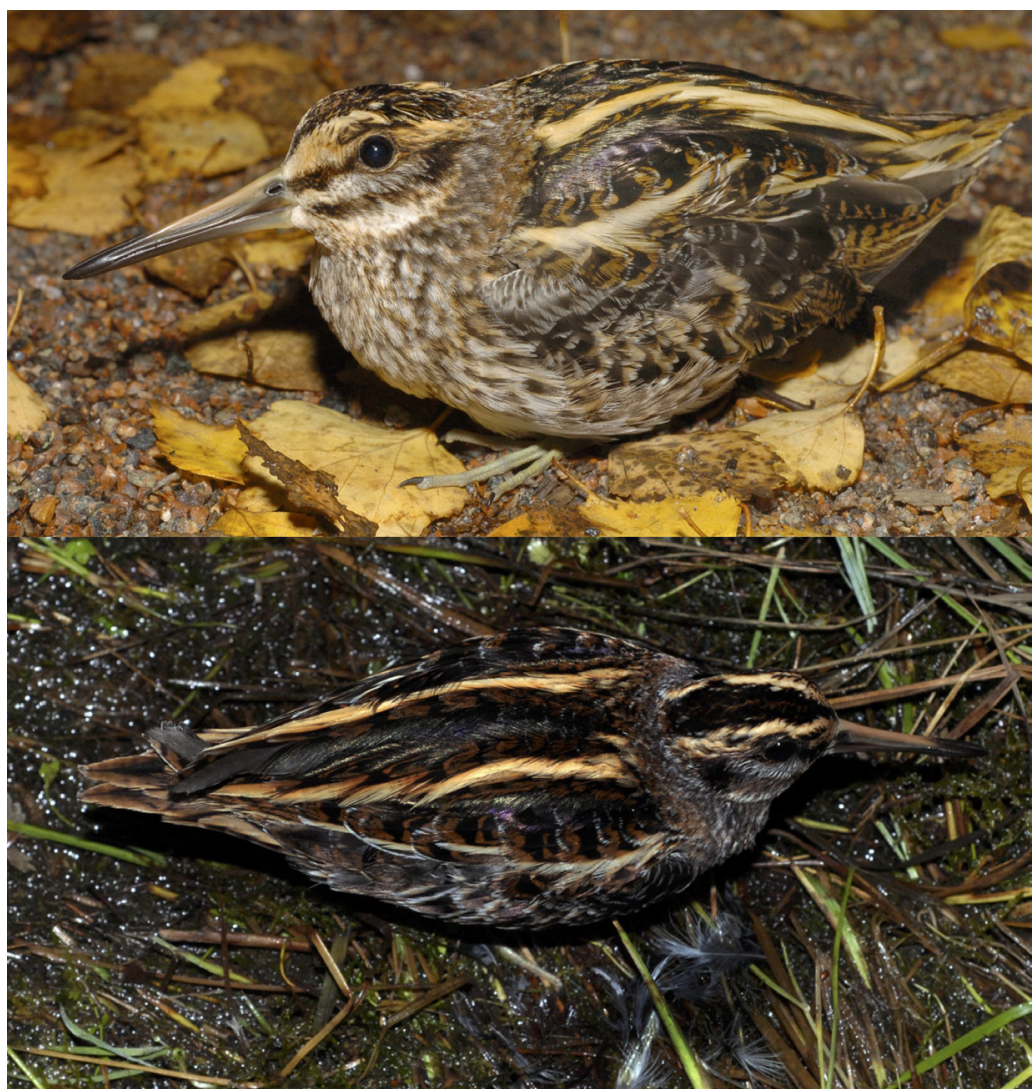

FIGURE 1. A Jack Snipe Lymnocryptes minimus showing its characteristic cryptic coloration on head, back and over tail coverts. When facing danger, the snipe lies down pressed to the ground vegetation and ends up virtually invisible for predators. Photos: Christer Elderud.

- En dvärgbeckasin Lymnocryptes minimus som visar sin kryptiska färgteckning på huvud, rygg och övergump. När dvärgbeckasinen känner sig hotad trycker den tätt mot markvegetationen och blir praktiskt taget osynlig för predatorer. Foton: Christer Elderud. size in these areas are either unknown (Morozov 2002) or vary greatly (Rose \& Scott 1997, Devort et al. 2001, Kalchreuther 2003). In Sweden the species is mainly found in the boreal subalpine region, but it is also estimated that about one hundred pairs regularly breed in inaccessible marshlands in the central parts of southern Sweden (Nilsson \& Nilsson 1978, Ottosson et al. 2012).

For being such a widespread and not uncommon bird, the Jack Snipe easily escapes detection due to its secretive behaviour (Jackson 2004). The species is therefore scarcely observed in systematic monitoring programs in its main breeding habitats (e.g. Lindström et al. 2015). Even during migration the Jack Snipe is hard to find owing to its skulking habits and cryptic plumage coloration (Sikora 2005; Figure 1) as well as its reluctance to fly in daylight (Olivier 2007). These circumstances have created major challenges for appropriate methods of capturing birds for ringing (Lepley et al. 2005). Therefore, Jack Snipe is one of the least studied species amongst the European waders. One of few chances of capturing Jack Snipe in active flight is when the birds move from resting sites to foraging sites during crepuscular flight (Le Bobinnec 1976). Having experienced this phenomenon at Lake Tåkern a few times back in the 1960 s and 1970s, we once again set out to try capturing Jack Snipes using mist nets during late evening. The project started in September 2005 and continued for ten consecutive autumn seasons (mid-September to mid-November) using mist-netting along the very same partially muddy shoreline. The aim was to gain improved knowledge 


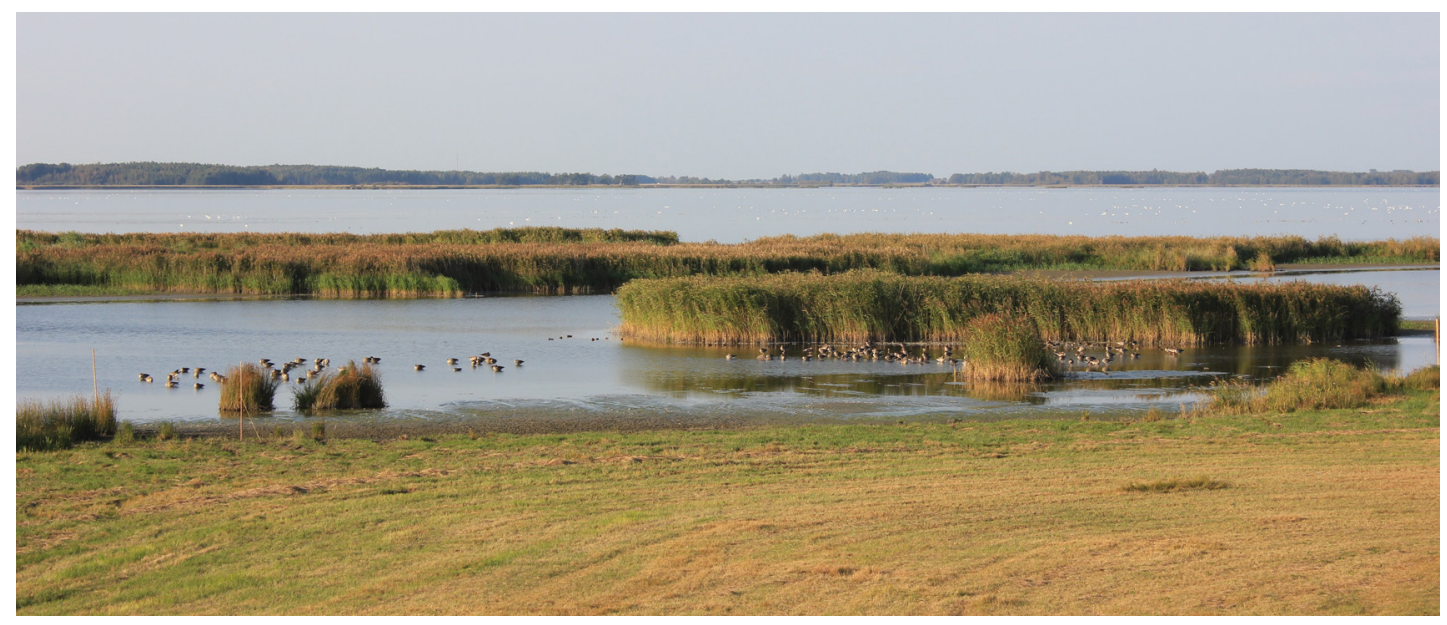

FIGURE 2. The partially muddy shore at Lake Tåkern where Jack Snipe Lymnocryptes minimus trapping was carried out. Photo: Adam Bergner. - Strandkanten vid sjön Tåkern där fångst av dvärgbeckasiner Lymnocryptes minimus har skett. Foto: Adam Bergner.

of the occurrence and migratory movements of this littlestudied species at a stopover location during autumn migration.

\section{Methods}

\section{STUDY AREA}

The ringing activities were carried out on wet meadows near Glänås at the southern shore of the shallow, moderately eutrophic Lake Tåkern, located in southern central Sweden $\left(5^{\circ} 21^{\prime} \mathrm{N}, 14^{\circ} 50^{\prime} \mathrm{E}\right)$. The meadows were restored in the early 2000 s by means of clearing emergent shrubs and mowing dense grass vegetation. After restoration, the meadows have been annually managed using mechanical haymaking in late summer. Nowadays, the area consists of an open and flat meadow that gradually merges into partially exposed mudflats near the shorelines (Figure 2). As the water level in the lake is artificially lowered by $20-25 \mathrm{~cm}$ in the autumn, the mudflats that are attractive for foraging waders increase in size. Most mudflats are covered in sparse and low stands of slender tufted-sedge Carex acuta, nodding beggartick Bidens cernua, and celery-leaved buttercup Ranunculus sceleratus. In the shallow waters within the nearest hundred metres from the shoreline there are a few islands covered in emergent vegetation of common reed Phragmites australis, lesser bulrush Typha angustifolia and common club-rush Schoenoplectus lacustris.

\section{TRAPPING OF JACK SNIPE}

The trapping was carried out during ten consecutive autumn seasons (2005-2014) by regular ringing between mid-September and mid-November. Ringing was not performed every night but was limited by time and weather constraints (e.g., no trapping in rain or heavy winds). In total, trapping was carried out for 164 nights over the years. During the ringing sessions a maximum of eight standard wader mist nets (length $9 \mathrm{~m}$, height $2.1 \mathrm{~m}$, mesh size $30 \mathrm{~mm}$ ) were placed perpendicular to the shoreline in suitable areas offering attractive mudflats. When possible, the nets were placed near areas showing obvious signs of Jack Snipes that had left behind characteristic footprints and small holes from probing for food items in the mud. The mist nets were prepared for trapping approximately half an hour prior to dusk and remained opened for up to four hours after dusk. The nets were checked for captured birds every half hour using flashlights. On three occasions, standard walk-in funnel traps (see Lindström et al. 2005) were used near places where there were signs of recent activity of Jack Snipes. The wader traps were checked for captured birds every hour using flashlights.

\section{AGEING}

The birds captured during autumn migration at Lake Tåkern were carefully examined and documented in order to assess the age of as many birds as possible. Existing literature was used as a reference, but during 
the ongoing project new findings regarding ageing of the species in Europe were published, as a result of examining ringed birds and birds retrieved from hunting bags (Devort et al. 2017, Fokin \& Fokina 2019).

In general, the literature on how to discriminate adults from juveniles is limited, mainly due to the lack of studied material and an apparent low level of distinguishable physiological traits in Jack Snipe. The few available methods of ageing generally "requires a practice one only acquires after having analysed a great number of birds" (Olivier 2007). Folkestad (1974), cited by Cramp \& Simmons (1983) and Rouxel (2000), argued that the most useful criteria are proposedly small differences in fine details on tail feathers and under-tail coverts. According to his material juvenile birds have relatively narrow and finely pointed tips of the second and third tail feathers (counting from the central pair), whereas these feathers in adult birds are relatively broad with rounded tips. Regarding the under-tail coverts, adult birds show a somewhat more distinct blackish-brown subterminal patch spreading well onto the vane of the feather, whereas juvenile birds exhibit whitish feathers with indistinct yellowishbrown subterminal shaft-streaks.

However, later systematic analyses of an extensive material of 3,262 dissected Jack Snipes (Devort et al. 2001) concluded that these two criteria are neither convincing nor reliable because of the percentage of errors and the great number of unidentifiable birds. According to the same author, and further developed by Devort et al. (2017), the only reliable and widely adopted method for age determination in Jack Snipe is related to indistinct differences in the pattern of the two outer tail feathers. In juveniles, the apical extremity of each feather is pointed with a fine black line along the shaft. In adults, the extremity is more rounded with, at its tip, a dark and rather large apical area. The use of this method apparently permits a reliable estimation of age in more than $80 \%$ of the examined birds. For the birds captured at Lake Tåkern the latter criteria have been used for ageing of the birds (see Figure 3 for examples). A cautious approach has been practiced, and birds exhibiting ambiguous traits, even slightly so, have been left unaged.

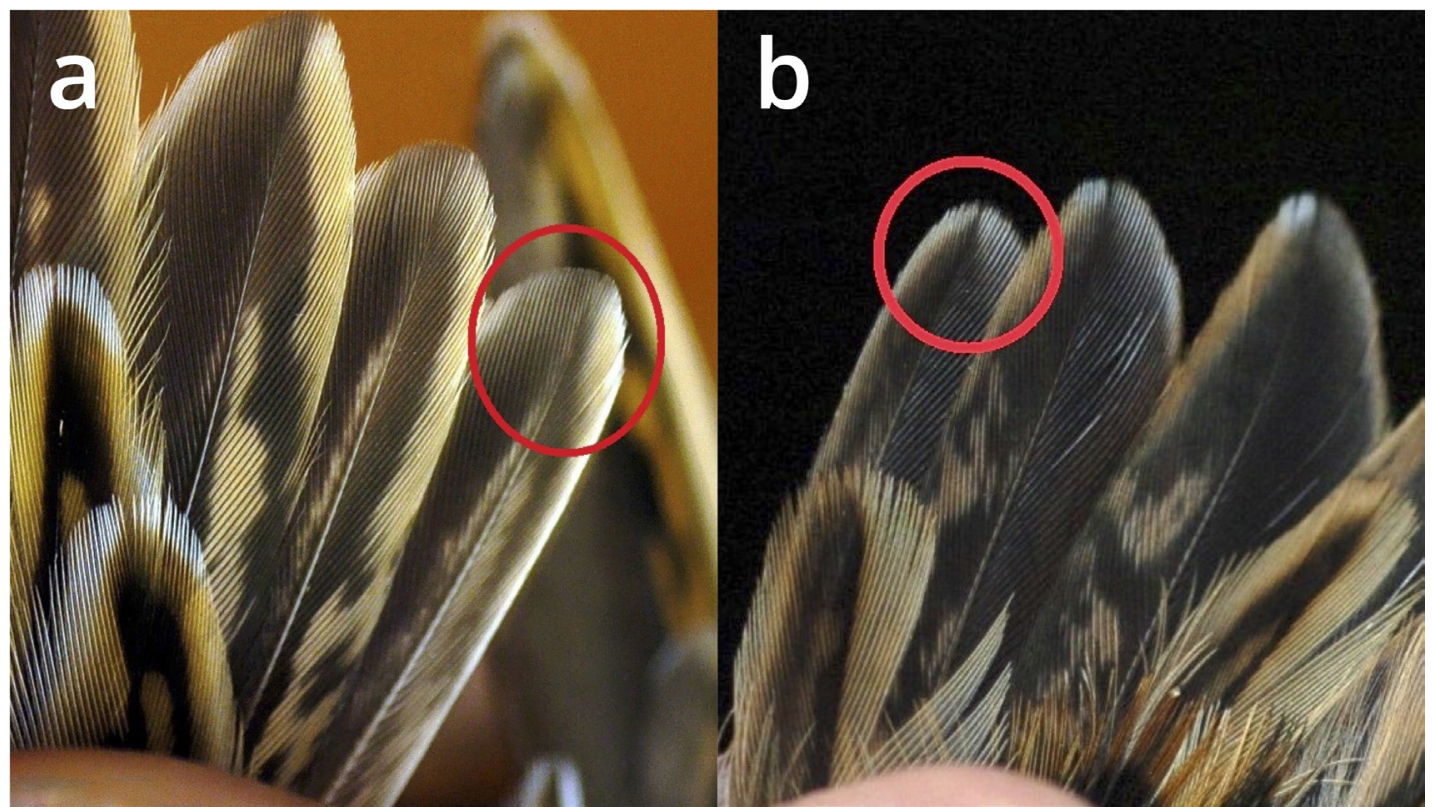

FIGURE 3. Examples of patterns on the outer tail feather (red ring) of Jack Snipes Lymnocryptes minimus assessed as (a) adult, and (b) juvenile. Notice that the feather of the juvenile bird exhibits a narrow black line at the end of the vane that separates two pale spots. The feather of the adult bird exhibits a rather broad black line at the end of the vane and a white or pale cream spot on one side of the feather.

- Exempel på färgteckningen på de yttre stjärtfjädrarna (röd ring) hos (a) adulta och (b) juvenila dvärgbeckasiner Lymnocryptes minimus. Notera att fjädern hos den juvenila fågeln har en smal svart linje som separerar två bleka fläckar på fjäderns topp. Fjädern på den adulta fågeln har en relativt bred svart linje med en vit eller blekt gräddfärgad fläck på ena sidan av fjäderns topp. 


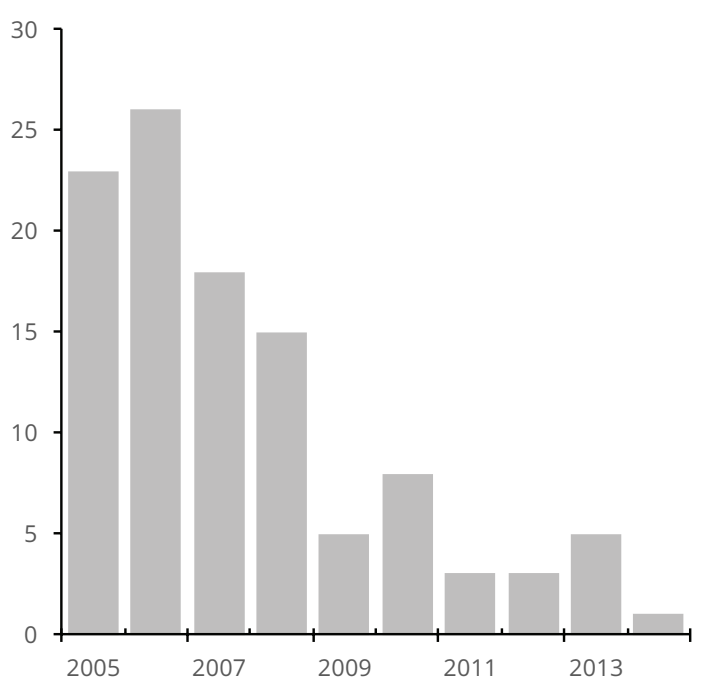

FIGURE 4. The number of Jack Snipes Lymnocryptes minimus ringed at Lake Tåkern each year during the period 2005-2014.

- Antalet dvärgbeckasiner Lymnocryptes minimus som ringmärkts vid Tåkern per år under perioden 2005-2014.

\section{BIOMETRIC MEASUREMENTS}

In many, but not all, of the captured birds a set of standard biometric measurements were recorded including wing length, bill length, and the length of tarsus, following Baker (2016). Body mass was recorded to the nearest 0.1 gram using digital scales. The data on biometric measurements was analysed for adults and juveniles, respectively, using non-parametric statistics (two-tailed Mann-Whitney U-test with a confidence interval of $95 \%$ ).

\section{Results}

\section{TRAPPING AND RINGING}

During a total of 164 evenings over the course of ten consecutive autumn seasons, a total of 107 Jack Snipes were captured (Figure 4). In addition to the birds captured using mist-netting another three birds were caught in wader traps at night, but these were excluded from the data analysed in this study. Among the mist-netted birds all but two were captured within the first two hours after dusk. Jack Snipes were captured between 11 September and 13 November. The passage peaked during the first ten days of October with the median date for all birds, regardless of age, being 7 October (Figure 5). The passage peaked on average a few days earlier for juvenile birds (median 2 October, interquartile range 8 days) than for adult birds (median 9 October, interquartile range 13.5 days), but the difference in timing was not statistically significant $(U=460, Z=-1.45, p=0.15)$.

\section{MOVEMENTS AND RINGING RECOVERIES}

So far, the ringing efforts have resulted in one recovery from Pas-de-Calais in north-western France, on 6 November 2008 , where a bird was killed during hunting nearly two years after it was ringed at Lake Tåkern (on 13 October 2006). The distance from the ringing site to the recovery site is $1,163 \mathrm{~km}$. This finding, together with an older recovery from Sicily, Italy, in 1966 (Elderud 2011), suggests that the Jack Snipes passing Lake Tåkern migrate towards southwest and that some birds spend the winter in Mediterranean marshlands. Out of the 107 birds ringed only six were recaptured in the same location during the same autumn, ranging from four to 32 days between ringing and recapture. A bird ringed at Lake Tåkern on 9 October 2008 was recaptured at the same location on 20 October 2009, representing the

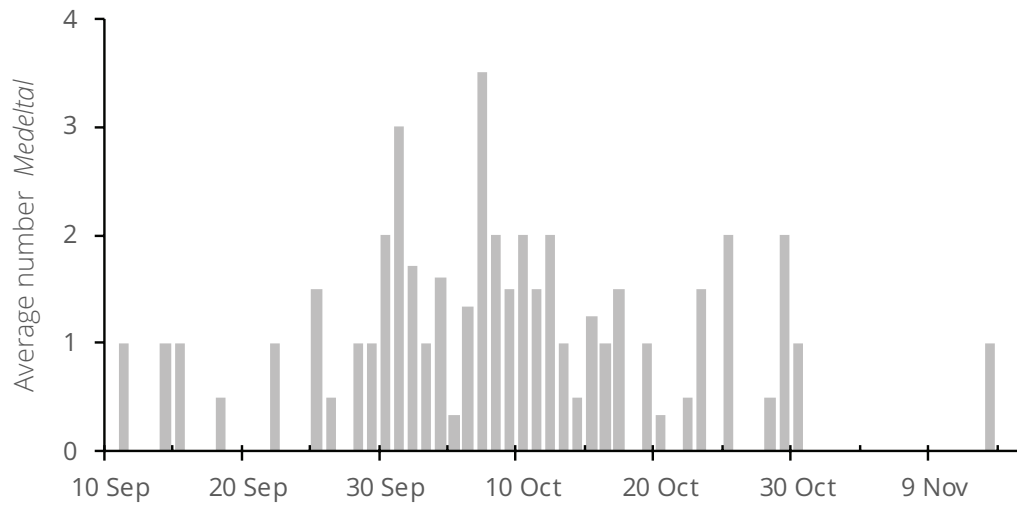

FIGURE 5. The autumn passage of Jack Snipe Lymnocryptes minimus at Lake Tåkern visualized as the average number of Jack Snipes ringed each date during the years 2005-2014. The median date for the ringed birds is 7 October.

- Höstpassagen hos dvärgbeckasin Lymnocryptes minimus vid Tåkern visualiserad som det genomsnittliga antalet fåglar som ringmärkts per datum under åren 2005-2014. Mediandatum för de ringmärkta fåglarna är den 7 oktober. 
TABLE 1. Some morphometrics of the Jack Snipes Lymnocryptes minimus captured at Lake Tåkern during 2005-2014. - Några kroppsmått hos dvärgbeckasiner Lymnocryptes minimus fångade vid Tåkern under åren 2005-2014.

\begin{tabular}{lccccc}
\hline $\begin{array}{l}\text { Measurement } \\
\text { Mått }\end{array}$ & $\begin{array}{l}\text { Sample size } \\
\text { Antal }\end{array}$ & $\begin{array}{l}\text { Range } \\
\text { Spann }\end{array}$ & $\begin{array}{l}\text { Median } \\
\text { Median }\end{array}$ & $\begin{array}{l}\text { Average } \\
\text { Medelvärde }\end{array}$ & $\begin{array}{l}\text { Standard deviation } \\
\text { Standardavvikelse }\end{array}$ \\
\hline Wing length $(\mathrm{mm})$ & 57 & $103-117$ & 111 & 110.9 & 3.2 \\
Weight $(\mathrm{g})$ & 31 & $45-87$ & 59 & 59.7 & 9.9 \\
Bill length $(\mathrm{mm})$ & 83 & $36-45$ & 40 & 40.3 & 1.6 \\
Tarsus length $(\mathrm{mm})$ & 3 & $25-28$ & 26 & 26.3 & - \\
\hline
\end{tabular}

only example of a Jack Snipe that reused a previously utilized stopover site during migration.

\section{AGE DISTRIBUTION}

Following previously presented material on agediscriminating characters (particularly Devort et al. 2001, 2017) we have examined the outer tail feathers of a majority of the 107 Jack Snipes captured. Out of these, only $50 \%$ have been aged with certainty based upon the look on the outer tail feathers, as shown in Figure 3. When age was assessed, there was a slight dominance of adult birds ( $54 \%$ ) compared to juvenile birds ( $46 \%$ ).

\section{BIOMETRY}

Data on bill length, wing length, weight, and tarsus length were recorded in order to assess the morpho-

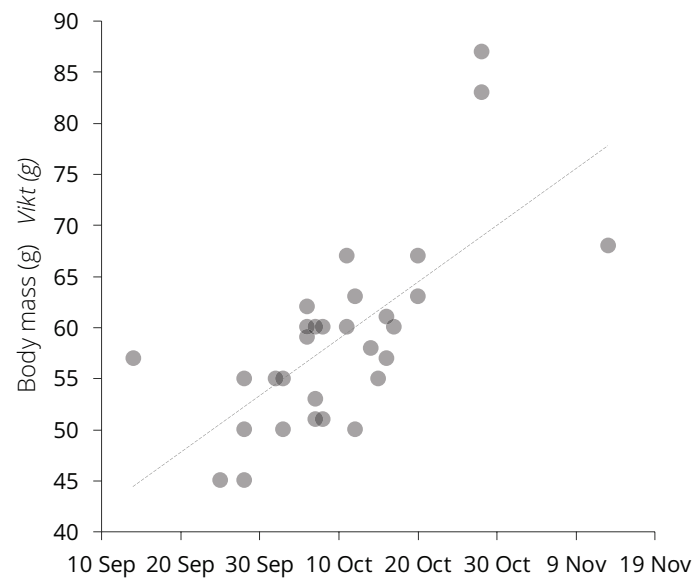

FIGURE 6. The relationship between trapping date and body mass in Jack Snipes Lymnocryptes minimus $(n=30)$ captured at Lake Tåkern 2005-2014 ( $y=0.557 x+42.198, r 2=0.47, F=24.55, p<0.001)$.

- Förhållandet mellan fångstdatum och kroppsvikt hos dvärgbeckasiner Lymnocryptes minimus $(n=30)$ vid Tåkern under åren 2005-2014 $(y=0.557 x+42.198, r 2=0.47, F=24.55, p<0.001)$. metric variation in the species (Table 1). There were no significant age-related differences in bill length (adults: mean $40.3 \mathrm{~mm} \pm 1.41 \mathrm{~mm} \mathrm{SD}$; juveniles: mean $40.1 \mathrm{~mm}$ $\pm 1.66 \mathrm{~mm} \mathrm{SD} ; \mathrm{U}=505.5, \mathrm{p}=0.98)$ nor wing length (adults: $111.0 \pm 3.39 \mathrm{~mm}$; juveniles: $111.4 \pm 2.61 \mathrm{~mm}$; $\mathrm{U}=234.5, \mathrm{p}=0.79$ ) or body mass (adults: $57.3 \pm 7.20 \mathrm{~g}$; juveniles: $59.1 \pm 11.3 \mathrm{~g}$; $U=49.5, p=0.94)$. The weight of the birds differed some 42 gram between the heaviest and the lightest bird across all years. In general, the weight of captured birds increased significantly by on average $0.56 \mathrm{~g}$ per day as the autumn progressed (Figure 6). During evenings in which more than one Jack Snipe were captured the difference in weight of these birds ranged from 3 to 13 gram, with an average weight difference of 6.4 gram. Unfortunately, the few birds that were retrapped were not weighed.

\section{Discussion}

During more than 160 nights of mist-netting we have managed to ring a total of 107 Jack Snipes, complementing previous knowledge on migratory phenology, gathering biometric data, and providing insights to appropriate methods of capturing this unobtrusive species. The efforts confirm that Jack Snipes can be appropriately captured near places offering attractive foraging sites at timing of crepuscular flight. Experiences from Lake Tåkern indicate that most birds are captured within the first two hours after dusk, presumably coinciding with the time of the highest activity of crepuscular flight (cf. Le Bobinnec 1976). This theory is further supported by the fact that no birds were flushed from the meadows while preparing the mist nets for trapping, most likely because the snipes resided elsewhere prior to dusk. Already within an hour after dusk there were signs of recent Jack Snipe activity 
in the mud near the mist nets, and on rare occasions birds were then flushed close to the nets and captured. Since no birds were captured in the mist nets during evenings with night light (e.g., from full moon) we suspect that Jack Snipes, like other Snipes with large eyes and mainly nocturnal foraging habits (Thomas et al. 2006), have the ability to visually detect and avoid the mist nets during crepuscular flight.

Most information on migratory phenology in the Jack Snipe has been gathered by means of spontaneous observations of birds that have been flushed in, e.g., meadows at time of migration. A few studies have practiced standardized censuses (e.g., transect walks) to flush roosting snipes and record the temporal variation in the number of birds at stopover during migration (e.g. Kruszyk \& Zbroński 2002). To some extent, information gathered from hunting has also contributed to improved knowledge on migratory phenology of the species (e.g. Massoli-Novelli 1988).

There have been fewer studies based primarily upon ringing. The ringing carried out at Lake Tåkern suggests that the duration of autumn migration is relatively extended and ranges from mid-September to at least mid-November. The passage sees a rather distinct peak during the first ten days of October, roughly coinciding with the average arrival of the first Jack Snipe to wintering grounds in Ireland (Cooney 2017), but five weeks earlier than the peak of migration in north-western Italy (Battisti \& Soldato 2018). A study on migratory phenology of Jack Snipes at stopover in northern Poland, Cenian \& Sikora (1997) showed that the autumn passage peaked during the third week of October. The Polish study involved no ringing but standardized censuses based on birds flushed from specific meadows at stopover. No similar studies have been performed at Lake Tåkern parallel to the crepuscular ringing presented here. The two studies may not be directly comparable but instead treat different aspects of migratory phenology in the species. Furthermore, it is possible that the Jack Snipes passing Lake Tåkern belong to different populations than Polish birds do, and the timing of migration may therefore differ.

Adding to the timing of migration is the variation in body weight in general, and the presence of exceptionally heavy birds in particular, which raises intriguing questions regarding the length of individual migration legs amongst birds passing Lake Tåkern. Several species of waders gain large fat loads prior to performing long endurance flights (Evans \& Davidson 1990), and this is particularly pronounced in the long-distance migratory Great Snipe Gallinago media (Klaassen et al. 2011). Populations of Jack Snipe breeding east of $45^{\circ} \mathrm{E}$ apparently perform similar long-distance migration, but whether this includes long-endurance flights is unknown, as is the possible occurrence of longdistance migrants of eastern origin amongst the Jack Snipes passing through Europe. Even in the absence of birds of eastern origin, there is still a possibility that European migrants perform long-endurance flights, for example to wintering grounds in north-western Africa, a journey which would certainly require large fat loads.

Another possibility that should not be ruled out is that, since Jack Snipes occasionally winters in southern Scandinavia, the birds captured at Lake Tåkern may include some individuals with wintering grounds not far from Lake Tåkern. However, to what extent Jack Snipes regularly occur in southern Sweden during winter is also inadequately studied due to difficulties to detect wintering birds by chance. A study from Poland (Sikora \& Maniakowski 2000) argued that small groups of wintering birds congregate near ice-free waters, for example at fish ponds and along sewage canals. A similar behaviour was described in Denmark where several wintering birds occasionally gathered near ice-free waters during sudden cold spells (Pedersen 1989). During a particularly sudden cold spell in February 2021 , following a couple of unusually mild winter months in Linköping, just $50 \mathrm{~km}$ from Lake Tåkern, at least six Jack Snipes were found roosting along a small stream within just a few hundred metres of each other (personal observations). This suggests that similar events occur in southern Sweden, albeit less frequently documented. Information is still scarce as to the origin of wintering birds as well as their degree of site fidelity between years.

Being an inconspicuous and poorly investigated species, there is a need for further studies of the Jack Snipe to contribute to a greater understanding of its ecology. Capturing enough birds to gain sufficient ringing data for analyses of morphology and migratory phenology is still, however, a troublesome task, even though the methods of trapping birds during migration and on wintering grounds have been refined during 
the last two decades (e.g. Sikora \& Maniakowski 2000, Sikora 2005, Lepley et al. 2005). The knowledge on agediscriminating plumage characters as well as sexual dimorphism (e.g. Sikora \& Dubiec 2007) in the species has also greatly improved, and further knowledge can be gained from careful examination of hunting bags across Europe (e.g. Morozov 2002, Fokin \& Fokina 2019).

Since the Jack Snipe continues to be difficult to appropriately monitor in its breeding habitats mainly due to inaccessibility, it may be a suitable model species to monitor using mist-netting on strategic sites spread along expected migration routes. It would be advantageous to find ringing sites that could be used under standardized conditions to ensure comparable long-term data. The ringing of Jack Snipe at Lake Tåkern was not implemented with strictly standardized methods but clearly demonstrated some of the challenges of maintaining a ringing site in a constantly changing habitat. A few years after the restoration of the meadows at the ringing site the number of captured Jack Snipes started decreasing at a steady rate. This decrease roughly coincided with the establishment of emergent vegetation at the expense of mudflats, which probably turned the habitat less attractive for foraging to Jack Snipes during migration. Where mudflats are not naturally sustained, regular management may therefore be necessary to ensure the continuity of such stopover sites.

Even though the ringing site at Lake Takkern might have offered unusually favourable conditions for trapping Jack Snipes, at least in the first few years, it is still difficult to put the number of 107 birds into perspective. For comparison, the number of Common Snipes Gallinago gallinago captured at the very same location during the period did not exceed twenty birds. Since the latter is generally considered a more abundant species, at least in southern Sweden, this raises questions about the actual size of the migratory population of Jack Snipe, suggesting that it might be more abundant than previously expected. While the current project has improved the knowledge on certain aspects of the species, it has also produced new questions needed to be answered. The Jack Snipe is undoubtedly a secretive bird and its presence both at breeding grounds and during migration is largely unnoticed by most people, including experienced ornithologists.

\section{Acknowledgements}

We are grateful for the help provided by local ringers and assistants connected to Tåkern Field Station over the years. The valuable comments by three reviewers on an earlier draft greatly improved the manuscript. The ringing project was financially supported by the Tåkern Fund. This is contribution no. 111 from Tåkern Field Station.

\section{References}

Baker J. 2016. Identification of European non-passerines. British Trust for Ornithology, Thetford, UK.

Battisti A \& Soldato G. 2018. Regular wintering of Jack Snipe (Lymnocryptes minimus) in NW Italian heathland habitat. Rivista Italiana di Ornitologia 88: 3-8. https://doi.org/10.4081/rio.2018.334

Cenian Z \& Sikora A. 1997. Jesienna wędrówka bekasika Lymnocryptes minimus w północno-zachodniej Warmii i na Pobrzeżu Gdańskim w roku 1996. Notatki Ornitologiczne 38: 215-222.

Cooney T. 2017. Migration phenology of Jack Snipe Lymnocryptes minimus at an Irish coastal wetland. Irish Birds 10: 463-468.

Cramp S \& Simmons KEL (eds). 1983. The Birds of the Western Palearctic. Vol. III. Waders to Gulls. Oxford University Press, Oxford, UK.

Devort M, Février P \& Olivier G-N. 2oo1. Contribution à l'étude du statut de la bécassine sourde Lymnocryptes minimus. Etude de l'âge-ratio par analyse du plumage. Etude statistique des prélèvements. C.I.C.B. \& F.N.C., Paris, France.

Devort M, Leray G \& Ferrand Y. 2017. Age determination of Jack Snipe by plumage characteristics. Wader Study 124: 60-65.

Elderud C. 2011. Den vanliga dvärgbeckasinen - förbisedd i Sverige på hösten. Vingspegeln 30: 80-87.

Evans PR \& Davidson NC. 1990. Migration strategies and tactics of waders breeding in arctic and north temperate latitudes. Pp 387398 in Bird Migration: Physiology and Ecophysiology (Gwinner E, ed). Springer, Berlin. https://doi.org/10.1007/978-3-642-74542-3_25

Fokin SY \& Fokina NS. 2019. Determination of age and sex of the Common Snipe (Gallinago gallinago) and Jack Snipe (Lymnocryptes minimus) by plumage. Actual Issues of Wader Studies in Northern Eurasia. Proceedings of the XI International Scientific and Practical Conference: 263-269.

Folkestad AO. 1974. Ageing the Jack Snipe, Lymnocryptes minimus. Wader Study Group Bulletin 13: 9-10.

Fransson T, Österblom H \& Hall-Karlsson S. 2008. Swedish Bird Ringing Atlas. Vol. 2. Grouses-Woodpeckers. [In Swedish with English summary]. Swedish Museum of Natural History, Stockholm.

Jackson SF. 2004. Monitoring methods for non-breeding snipe. BTO Research Report No. 355. British Trust for Ornithology, Thetford, UK.

Kalchreuther H. 2003. On the population status of the jack snipe (Lymnocryptes minimus). Game \& Wildlife Science 20: 175-193.

Klaassen RHG, Alerstam T, Carlsson P, Fox JW \& Lindström Å. 2011. Great flights by great snipes: long and fast non-stop migration over benign habitats. Biology Letters 7: 833-835. https://doi.org/10.1098/ rsbl.2011.0343

Kruszyk R \& Zbroński R. 20o2. Migration of waders (Charadrii) at the sediment-ponds and floods of coal-mines in Jastrzębie Zdrój. Ring 24: 105-119.

Le Bobinnec GJ-P. 1976. Introduction à la synécologie des limicoles (Aves: Charadrii) dans la presqu'ile de Guérande. Thèse Doctorat Vétérinaire, Université Paul Sabatier, Toulouse, France. 
Lepley M, du Rau PD, Viellé M, Pineau O \& Monval JYM. 2005. Capturing Jack Snipe Lymnocryptes minimus with mobile horizontally held nets. Ringing \& Migration 22: 167-170. https://doi.org/10.1080/ 03078698.2005 .9674327

Lindström A, Klaassen M \& Lanctot R. 2005. The foldable "Ottenby" walk-in trap: a handy and efficient wader trap for expedition conditions. Wader Study Group Bulletin 107: 50-53.

Lindström Å, Green M, Husby M, Kålås JA \& Lehikoinen A. 2015. Large-scale monitoring of waders on their boreal and arctic breeding grounds in northern Europe. Ardea 103: 3-15. https://doi. org/10.5253/arde.v10311.a1

Massoli-Novelli R. 1988. Migration, ringing recoveries and some bag statistics of Common, Great and Jack Snipe in Italy. Proceedings of the third European Woodcock and Snipe Workshop by the Woodcock and Snipe Research Group (WSRG): 16-19.

Morozov VV. 2002. Former and recent status of the jack snipe (Lymnocryptes minimus) breeding range in the European part of Russia. Game \& Wildlife Science 19: 221-233.

Nilsson SG \& Nilsson IN. 1978. Population, habitat and display activity of the Jack Snipe Lymnocryptes minimus in southern Sweden. Vår Fågelvärld 37: 1-8.

Olivier G-N (ed). 2007. The Jack Snipe Lymnocryptes minimus. $\mathrm{OMPO} / \mathrm{CICB}$, Paris, France.

Ottosson U, Ottvall R, Elmberg J, Green M, Gustafsson R, Haas F, Holmqvist N, Lindström Å, Nilsson L, Svensson M, Svensson S \& Tjernberg M. 2012. Fåglarna i Sverige - antal och förekomst [In Swedish with English summary]. Sveriges Ornitologiska Förening, Halmstad.

Pedersen MB. 1989. Wintering strategy of the Jack Snipe in Denmark. Dansk Ornitologisk Forenings Tidsskrift 83: 69-73.
Pedersen MB. 1995. Opportunistic behavior as key-determinant in the winter strategy of the Jack Snipe Lymnocryptes minimus in southern Scandinavia. Wader Study Group Bulletin 78: 23-26.

Rose PM \& Scott DA (eds). 1997. Waterfowl Population Estimates. 2nd Edition. Wetlands International Publications 44. Wetlands International, Wageningen, The Netherlands.

Rouxel R. 200o. Snipes of the Western Palearctic. Eveil Nature, St-Yrieix-sur-Charente, France.

Sikora A. 2005. Catching Jack Snipe with dip-nets in the non-breeding season. Wader Study Group Bulletin 108: 70-75.

Sikora A \& Dubiec A. 2007. Sex identification of Jack Snipe Lymnocryptes minimus by discriminant analysis of morphometric measurements. Ardea 95: 125-133. https://doi.org/10.5253/078.095.0114

Sikora A \& Maniakowski M. 20oo. Zimowanie bekasika Lymnocryptes minimus w północnej i środkowej Polsce. Notatki Ornitologiczne 41: 225-238.

Smiddy P. 20o2. Jack Snipe - Lymnocryptes minimus. In The migration atlas: movements of the birds of Britain and Ireland (Wernham C, Toms M, Marchant J, Clark J, Siriwardena G \& Baillie S, eds). British Trust for Ornithology, Thetford, UK.

Taylor PB. 1988. The distribution, status, movements and habitat of Jack Snipe, Common Snipe and Pintail Snipe in Africa. Proceedings of the third European Woodcock and Snipe Workshop by the Woodcock and Snipe Research Group (WSRG): 7-11.

Thomas RJ, Székely T, Powell RF \& Cuthill IC. 20o6. Eye size, foraging methods and the timing of foraging in shorebirds. Functional Ecology 20: 157-165. https://doi. org/10.1111/j.1365-2435.2006.01073.x

\section{Svensk sammanfattning}

Dvärgbeckasinen Lymnocryptes minimus hör till de minst studerade europeiska vadarna. Arten för ett undangömt leverne i vidsträckta och svårtillgängliga myrmarker främst från norra Skandinavien österut till Sibirien, vanligen i trakter där få människor bor. Omkring hundra häckande par förekommer också utspritt på sydsvenska höglandet, t. ex. vid Store Mosse nationalpark i Småland. I sitt västra utbredningsområde flyttar dvärgbeckasinen huvudsakligen till övervintringsplatser på Brittiska öarna och i sydvästra Europa samt nordvästra Afrika. I Sibirien, huvudsakligen öster om den 45:e längdgraden, är den häckande populationen i stället långflyttande med övervintringsområden i Afrika söder om Sahara.

På häckningsplatserna är dvärgbeckasinen normalt svårfunnen och svårinventerad. Också under flyttningen är dvärgbeckasinen en mycket diskret och svårsedd faggel som trycker hårt i fuktig gräsmark och ogärna flyger i dagsljus. Strax efter skymningen förflyttar sig dock beckasinerna mellan viloplatser och födoplatser i skydd av mörkret och är då möjliga att infånga för ringmärkning.

Vi undersökte höststräcket hos dvärgbeckasin vid sjön Tåkern i västra Östergötland $\left(58^{\circ} 21^{\prime} \mathrm{N}, 14^{\circ} 50^{\prime} \mathrm{E}\right)$ genom kvällsfångst med vadarnät längs en 100 meter lång öppen och lerig strandkant under tio höstsäsonger (2005-2014), från början av september till mitten av november. Metoden visade sig fungera väl, och totalt kunde vi fånga och ringmärka 107 dvärgbeckasiner under sammanlagt 164 fångstkvällar. Fåglar fångades mellan 11 september och 13 november med en tydlig sträcktopp under de tio första dagarna i oktober. Mediandatum för höstpassagen inföll den 7 oktober. Unga fåglar passerade överlag något tidigare (median 2 oktober, kvartilavstånd 8 dagar) än gamla fåglar (median 9 oktober, kvartilavstånd 13,5 dagar), men skillnaden var inte statistiskt signifikant. Alla fåglar utom två fångades i näten inom de två första timmarna 
efter solnedgång. Inte en enda fågel stöttes upp från fångstområdet då näten förbereddes för fångst strax innan skymningen. Redan en timme efter solnedgång gick det dock att finna färska fotspår och näbbavtryck från födosökande dvärgbeckasiner i dyn alldeles i närheten av fångstnäten. Inte en enda fågel nätfångades under kvällar med starkt månsken. Vi misstänker att beckasinerna med sitt välutvecklade mörkerseende helt enkelt lyckades upptäcka och undvika de tunna näten.

Ringmärkningen har resulterat i ett återfynd från Pas-de-Calais i nordvästra Frankrike, där en faggel sköts drygt två år efter märkning vid Tåkern. Tillsammans med ett tidigare återfynd av en Tåkernmärkt fågel från italienska Sicilien 1966 ligger detta inom fyndbilden för tidigare påträffade dvärgbeckasiner ringmärkta i Sverige.

Av våra 107 märkta dvärgbeckasiner har blott sex individer återfångats på samma plats under samma flyttningssäsong, som minst fyra dygn och som mest hela 32 dygn efter ringmärkning. Detta kan tyda på att de flesta beckasiner inte stannar så länge på denna rastplats utan snabbt flyttar vidare och ersätts av nyanlända fåglar. En fågel märkt 9 oktober 2008 återfångades vid Tåkern drygt ett år senare (20 oktober 2009), vilket utgör det enda exemplet på en individ som nyttjar samma rastplats under flera år.
Att åldersbestämma dvärgbeckasiner är relativt komplicerat och kräver god erfarenhet. I litteraturen anges numera att det i huvudsak endast är en karaktär som är utslagsgivande, nämligen färgteckningen på spetsarna hos de yttre stjärtpennorna. Av de vid Tåkern fångade făglarna har en stor andel (50\%) uppvisat olika grader av intermediära drag, varför åldern inte kunnat fastställas med säkerhet. Av de säkert åldersbestämda beckasinerna har de äldre fåglarna varit något mer dominerande ( $54 \%$ ) jämfört med de juvenila fåglarna (46\%). I likhet med flera tidigare författare som undersökt utslagsgivande dräktskillnader mellan unga och gamla fåglar rekommenderar vi att åldersbestämning görs med eftertänksamhet.

Eftersom dvärgbeckasinen är både svårsedd och svårinventerad hör den till en av de vadararter där kunskapen om bl. a. bevarandestatus och populationsstorlek för närvarande är bristfällig. Anpassad ringmärkning med standardiserad metodik kan bidra till att sprida ett visst ljus över dessa frågor. Vi föreslår att riktade satsningar bör göras för att fånga och ringmärka dvärgbeckasiner på lämpliga rastplatser i syfte att öka kunskapen om artens flyttningsvägar och möjligen också bevaka dess populationsutveckling i Europa.

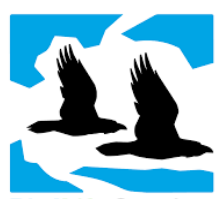

BirdLife Sverige

Ornis Svecica (ISSN 2003-2633) is an open access, peer-reviewed scientific journal published in English and Swedish by BirdLife Sweden. It covers all aspects of ornithology, and welcomes contributions from scientists as well as non-professional ornithologists. Accepted articles are published at no charge to the authors. Read papers or make a submission at os.birdlife.se.

Ornis Svecica (ISSN 2003-2633) är en fritt tillgänglig granskad vetenskaplig tidskrift som ges ut på svenska och engelska av BirdLife Sverige. Den täcker ornitologins alla områden och välkomnar bidrag från såväl forskare som icke-professionella ornitologer. Accepterade uppsatser publiceras utan kostnad för författarna. Läs uppsatser eller skicka in ditt bidrag på os.birdlife.se. 